Courses of all branches of Higher Education. University Press, The University Grant Commission: India; 2005 [cited August 2016]. p- 8 .Available from: https://www.ugc.ac.in/oldpdf/modelcurriculum/env. pdf

14. Rhoads RA. How civic engagement is reframing liberal education. Peer Review. 2003 Spring;5(3):25-8.

15. Young IM. Justice and the politics of difference. Princeton University Press; 2011. Iris Marion Young (1999) Residential segregation and differentiated citizenship. Citizensh Stud. 1999 3:2, 237-252, DOI: 10.1080/13621029908420712.

16. Young IM. Residential segregation and differentiated citizenship. Citizensh Stud. 1999;3(2):237-52. DOI: 10.1080/13621029908420712

17. Ravindran GD, Kalam T, Lewin S, Pais P. Teaching medical ethics in a medical college in India. Natl Med J India 1997;10:288-9.

18. Whiting K, Konstantakos L, Misiaszek G, Simpson E, Carmona L. Education for the sustainable global citizen: What can we learn from Stoic philosophy and Freirean environmental pedagogies? Education Sciences. 2018;8(4):204

19. United Nations Educational, Scientific and Cultural Organization. Global citizenship education: Preparing learners for the challenges of the 21st century. Paris: UNESCO; 2014[cited 2019 Jul 5]. Available from: https://unesdoc.unesco.org/ark:/48223/pf0000227729
20. Watts N, Adger WN, Agnolucci P, Blackstock J, Byass P, Cai W, et al. Health and climate change: policy responses to protect public health. Lancet 2015 Nov 7; 386(10006):1861-914. doi: 10.1016/S0140-6736(15)608546

21. Coulehan J,Williams PC,McCrary SV,Belling C.The best lackall conviction: biomedical ethics, professionalism, and social responsibility. Cambridge $Q$ Healthc Ethics. 2003Winter; 12(1):21-38.

22. Diwan V, Minj C, Chhari N, De Costa A. Indian medical students in public and private sector medical schools: are motivations and career aspirations different?-studies from Madhya Pradesh, India. BMC Med Educ. 2013;13(1):127.

23. Dhalla IA, Kwong JC, Streiner DL, Baddour RE, Waddell AE, Johnson IL. Characteristics of first-year students in Canadian medical schools. CMAJ. 2002;166: 1029 -35.

24. Boelen C. Towards unity for health. Geneva:WHO; 2000.

25. Dharamsi S, Ho A, Spadafora SM, Woollard R. The physician as health advocate: translating the quest for social responsibility into medical education and practice. Acad Med. 2011;86(9):1108-13.

26. Westheimer J, Kahne J. What kind of citizen? The politics of educating for democracy. Am Educ Res J. 2004; 41(2):237-69.

27. Gribble MO. Environmental health virtue ethics. Am J Bioeth. 2017 Sep 17(9):33-5. doi: 10.1080/15265161.2017.1353166.

\title{
Improving global access to medical ethics education: a free self-paced online course on the Peoples-uni website
}

\section{ROGER P WORTHINGTON, RAJAN MADHOK, RICHARD F HELLER}

\begin{abstract}
In an attempt to increase global access to education about medical ethics, a free fully online course was developed on the Peoples-uni Open Online Courses site. Students came from 60 countries and were more likely to be medical practitioners, have come from the global North, and to have heard about the course through the web than other students enrolled in the Peoples-uni Open Online Courses site. Students scored high marks on the five quizzes. A third of the students gained a certificate of completion. Course feedback was overwhelmingly positive. Students stated that they learned the most from the lesson on professionalism, while other topics such as patient rights and autonomy, legal
\end{abstract}

Authors: Roger P Worthington (rpworthington@gmail.com), Independent researcher, Lee Terrace, London SE3 9TB UK; Rajan Madhok (madhokrajan@ gmail.com), Chair, Board of Trustees, People's Open Access Education Initiative (Peoples-uni), Llanbedr DC, Wales LL151BQ; Richard F Heller (corresponding author - rfheller@peoples-uni.org), Coordinator and Trustee, People's Open Access Education Initiative (Peoples-uni), and Emeritus Professor, Universities of Manchester, UK, and Newcastle Australia, 59/96 Alfred Street, Milsons Point, NSW 2061, Australia.

To cite: Worthington RP, Madhok R, Heller R. Improving global access to medical ethics education: A free self-paced online course on the People'sUni website. Indian J Med Ethics. 2020 Jul-Sep; 5(3) NS: 235-40. DOI:10.20529/ IJME.2020.031.

Published online on March 28, 2020.

Manuscript Editor: Mala Ramanathan

Peer Reviewers: Satendra Singh and another anonymous peer reviewer

OIndian Journal of Medical Ethics, 2020 issues, and healthcare organisation and public health were also frequently mentioned. The course is an example of how open online courses can play a role in increasing awareness of medical ethics. Based on its analysis, the study identifies a need to attract interest in this area from low- and middle-income countries.

\section{Background}

The People's Open Access Education Initiative, (Peoples-uni, was developed "to contribute to improvements in the health of populations in low- to middle-income countries by building Public Health capacity via e-learning at very low cost" $(1,2)$. In addition to modules for academic credit leading to a master's level award, a set of Open Online Courses are available for selfpaced learning leading to certificates of completion, available without cost to anyone on the web, as well as for some special targeted audiences (3).

Courses include those developed especially for Peoples-uni, and those provided by others and hosted on the site. Various attempts were made to add a course on medical ethics to this site and replace the credit-bearing course, Public Health Ethics, offered previously by Peoples-uni from 2010 to 2012. The course we describe here, called Medical Ethics Online, originated from discussions held at workshops in Kolkata, India, in 2014-15 (4), where concerns were raised about the erosion of trust in the medical profession and the lack of medical ethics courses suitable for practising clinicians, trainees, and medical students $(5,6)$. A further need was identified for education to meet training demands in healthcare leadership and professionalism. This was reinforced by the team from Health 
Education England, who were promoting bilateral exchanges between the National Health Service (NHS) and developing countries, especially in South Asia and Africa. The now defunct NHS Global Health Exchange programme provided part of the sponsorship for the initial stages of the development of the course. The Kolkata meeting was convened by RM, and attended by RW as well as RM. Subsequent course development was led by RW, supported by a group of expert volunteers recruited from professional networks. The course was converted to the format for, and offered for enrolment through, the Open Online Courses site by RFH supported by the infrastructure team of Peoples-uni.

This report was designed to explore the experience of the development of a fully online course in medical ethics, and to perform a comparison of the characteristics of the students who enrolled with those on other courses on the same site, and between those who did and did not gain a certificate of completion. In addition, in order to improve the course for the future, we report which parts of the course were deemed most relevant to the audience, as identified by the students during course feedback.

\section{Methods}

We created a framework of topics that might be covered in such a course and identified 12 topics in five sections as the most relevant (see Table 3 for the list of sections and topics). Sixteen experts in medical ethics (seven from India, six of Indian origin but working in high-income countries now, and three from high-income countries) from a wide variety of backgrounds were asked to contribute to presentations covering each of these areas. The topics were selected based on the course director's international experience of curriculum design for law, ethics, and professionalism, as well as direct professional experience of medical regulation and setting codes of conduct.

This novel process for selecting topics was inspired by a desire to innovate and move away from old curriculum models for teaching the subject, many of which have been in place for several decades now and lack contemporary relevance. Other more specialised topics were deliberately omitted, as they will be included in a proposed higher-level course for those with a special interest and wanting to pursue the subject further (ie, to a level of detail that would not be relevant to all medical trainees and practitioners). The panel of contributors agreed on the topics to be included in the introductory course:Medical Ethics Online. As yet, Peoples-uni does not have the resources to develop a more advanced course. For those who wish to see the details of the course, it is freely available online for self-enrolment at http://ooc.peoples-uni.org. Because of the difficulty in writing case studies applicable in different jurisdictions and to different culture milieu, we decided to illustrate the course using case examples in law pertaining to India and the UK, rather than by including clinical cases studies. Subject matter experts in medical schools and professional colleges could be encouraged to write case studies applicable to legal and ethical norms in the countries and regions where they work.

RW edited the presentations, which were illustrated with case examples and legal references pertaining to India, the UK, and international declarations and conventions. The presentations were then converted to PDF files for ease of access, with hyperlinks connecting them to open access resources. The presentations were placed as a course on the Moodle platform of the Peoples-uni Open Online Courses site (http://ooc. peoples-uni.org), and included information about navigating the course as well as its learning outcomes. Each course section had an MCQ quiz, which did not require a pass grade. Students could repeat the quiz, and the highest recorded mark was used for analysis. An anonymous feedback questionnaire included three free text questions (answers to the first two questions were required):

i. "What is the main lesson you have learned from taking this course?"

ii. "Please use this space to give us feedback about the course."

iii, "Would you like to keep in contact about future courses or activities relating to medical ethics? Don't forget to add your email address if so."

A certificate of completion was automatically generated if the student obtained a grade in each quiz and completed the feedback questionnaire. The course is published under a Creative Commons licence.

After a pilot, the course was launched in April 2016, and has been available for enrolment since then. Students could enrol themselves in the Open Online Courses site (established on the Moodle online educational platform) and then enrol for the Medical Ethics course to be able to access and work through the materials at their own pace. The student experience of accessing various parts of the course was tracked through the course completion facility of Moodle, and unless a student enrolled more than once using a different username and password, there was no possibility of double counting, although individual students were able to enrol in multiple courses if they wished. There was no special advertising of the course, although previous Peoples-uni students were informed of the existence of Open Online Courses, and posts were made to various social media outlets to notify potential students of the existence of both Open Online Courses and the modules for academic credit.

Information was extracted in June 2019, representing three years of student enrolments. Data on user information collected during the enrolment process was extracted using the configurable reports facility of the Moodle platform, and data on quiz scores and certificates gained were accessed from the course reports. In order to compare the students enrolled 
in the Medical Ethics Online course with others enrolled on the Open Online Courses site, the demographic details of all other students were also obtained through the configurable reports facility, as described in a previous report (3).

Descriptive data were recorded and statistical analyses were performed using the chi square test. Attribution of the free text responses to the topics covered in the course (the first question of the feedback questionnaire) was performed twice each by two observers, and the (rounded) mean of the four measures was reported.

Ethics approval for this report was not sought-during the enrolment process, students are informed that their data may be analysed to improve the course and that in any resultant publication, it would not be possible to identify individual students.

Table 1.

Demographics of students taking Medical Ethics Online, in comparison with other students enrolled on other Peoples-uni Open Online Courses

\begin{tabular}{|c|c|c|c|}
\hline & $\begin{array}{l}\text { Medical } \\
\text { Ethics Online } \\
\text { (\% of those } \\
\text { with data) } \\
(\mathrm{N}=449)\end{array}$ & $\begin{array}{l}\text { All others } \\
\text { excluding } \\
\text { Medical } \\
\text { Ethics } \\
\text { Online (\% } \\
\text { of those } \\
\text { with data) } \\
\text { ( } \mathrm{N}=3711)\end{array}$ & $\begin{array}{l}\text { Chi square }\left(\chi^{2}\right) \\
\text { and p value } \\
\text { of difference } \\
\text { between } \\
\text { students } \\
\text { enrolled in } \\
\text { Medical Ethics } \\
\text { Online and } \\
\text { others }\end{array}$ \\
\hline \multicolumn{4}{|l|}{ Year of birth } \\
\hline Born before 1980 & $196(45 \%)$ & $1074(40 \%)$ & $\chi^{2} 4.3 ; p=0.04$ \\
\hline Born 1980 or after & $238(55 \%)$ & $1620(60 \%)$ & \\
\hline \multicolumn{4}{|l|}{ Gender } \\
\hline Female & $226(53 \%)$ & $1443(50 \%)$ & $\chi^{2} 2.3 ; p=0.13$ \\
\hline Male & $197(47 \%)$ & $1472(50 \%)$ & \\
\hline \multicolumn{4}{|l|}{ Occupation } \\
\hline Medical practitioner & $173(40 \%)$ & $689(26 \%)$ & $\begin{array}{l}\chi^{2} 38.8 \\
p<0.00001\end{array}$ \\
\hline Other & $168(39 \%)$ & $1360(51 \%)$ & \\
\hline Student & $92(21 \%)$ & $626(23 \%)$ & \\
\hline \multicolumn{4}{|l|}{ Geography } \\
\hline $\begin{array}{l}\text { US/UK/Ireland/ } \\
\text { Aust/NZ/Canada }\end{array}$ & $231(58 \%)$ & $1106(43 \%)$ & $\begin{array}{l}\chi^{2} 49.0 \\
p<0.00001\end{array}$ \\
\hline Indian subcontinent & $50(13 \%)$ & $231(9 \%)$ & \\
\hline Africa & $62(16 \%)$ & $620(24 \%)$ & \\
\hline Other & $53(13 \%)$ & $604(24 \%)$ & \\
\hline \multicolumn{4}{|l|}{$\begin{array}{l}\text { How did you hear } \\
\text { about the course? }\end{array}$} \\
\hline Heard through web & 277 (67\%) & $680(28 \%)$ & $\begin{array}{l}\chi^{2} 233.3 \\
p<0.00001\end{array}$ \\
\hline Other & 138 & $1723(72 \%)$ & \\
\hline
\end{tabular}

Note: The numbers do not add up to the total due to missing data

\begin{tabular}{|c|c|c|c|}
\hline \multicolumn{4}{|c|}{$\begin{array}{c}\text { Table 2: } \\
\begin{array}{c}\text { Medical Ethics Online students who gained completion certificates } \\
\text { by demographic groups }\end{array}\end{array}$} \\
\hline & \multirow[b]{2}{*}{$\mathbf{N}$} & N gained & \multirow[b]{2}{*}{$\begin{array}{l}\text { Chi square and } p \\
\text { value of difference } \\
\text { between students } \\
\text { who did and } \\
\text { did not gain a } \\
\text { certificate }\end{array}$} \\
\hline & & $\begin{array}{l}\text { Certificate } \\
(\%)\end{array}$ & \\
\hline \multicolumn{4}{|l|}{ Year of birth } \\
\hline Born before 1980 & 196 & $54(28 \%)$ & $\chi^{2} 1.85 ; p=0.17$ \\
\hline $\begin{array}{l}\text { Born } 1980 \text { or } \\
\text { after }\end{array}$ & 238 & $80(34 \%)$ & \\
\hline \multicolumn{4}{|l|}{ Gender } \\
\hline Female & 226 & $58(26 \%)$ & $\chi^{2} 6.39 ; p=0.011$ \\
\hline Male & 197 & $73(37 \%)$ & \\
\hline \multicolumn{4}{|l|}{ Occupation } \\
\hline $\begin{array}{l}\text { Medical } \\
\text { practitioner }\end{array}$ & 173 & $56(32 \%)$ & $\chi^{2} 12.7 ; p=0.0017$ \\
\hline Other & 168 & $39(23 \%)$ & \\
\hline Student & 92 & $41(45 \%)$ & \\
\hline \multicolumn{4}{|l|}{ Geography } \\
\hline $\begin{array}{l}\text { US/UK/Ireland/ } \\
\text { Aust/NZ/ } \\
\text { Canada }\end{array}$ & 231 & $83(36 \%)$ & $\chi^{2} 10.1 ; p=0.018$ \\
\hline $\begin{array}{l}\text { Indian } \\
\text { subcontinent }\end{array}$ & 50 & $10(20 \%)$ & \\
\hline Africa & 62 & $13(21 \%)$ & \\
\hline Other & 53 & $12(23 \%)$ & \\
\hline \multicolumn{4}{|l|}{$\begin{array}{l}\text { How did you } \\
\text { hear about the } \\
\text { course }\end{array}$} \\
\hline Through the web & 277 & $72(26 \%)$ & $\chi^{2} 9.19 ; p=0.002$ \\
\hline Other & 138 & $56(41 \%)$ & \\
\hline
\end{tabular}

\section{Results}

Up to June 2019, 4160 students had enrolled themselves on various Peoples-uni Open Online Courses, of whom 449 enrolled on the Medical Ethics course. Their demographic data are shown in Table 1.Compared with students enrolled in other courses, the Medical Ethics students were older and were more likely to be medical practitioners, to have come from a highincome country, and to have heard about the course through the internet.

Date of birth categories were collapsed from the four possible answers to the user information question to before and after 1980 for convenience. Students came from 60 countries, with $58 \%$ from high-income English-speaking countries in the global North, while students with similar demographics accounted for only $43 \%$ of other courses on the platform. The largest single source of students was the USA (132 students, $33 \%$ of those with data on their country of residence). 
Two-thirds of the students on the ethics course had heard about the course through the web, while less than a third of the other students had heard about their respective courses through the same channel. Students on the ethics course were more likely to be medical practitioners $(40 \%)$ than students of other courses (26\%).

\section{Certificates of completion}

140 students gained a certificate of completion (31\%). Table 2 shows that males, those who listed "student" as their occupation, those from the global North, and those who had heard about the course through channels other than the web were more likely than their demographic comparison groups to gain a certificate.

\section{MCQ quiz results}

There were five quizzes, one for each of the course sections, each having either $4,7,8$, or 9 questions, giving 32 questions overall. The distribution of scores was consistent across the quizzes. Overall, there was a score in 853 of the quizzes, of which 523 (61\%) were top marks.

\section{Feedback}

150 students submitted responses to the feedback questionnaire (this was one of the requirements to gain a certificate; 10 students who submitted responses had not completed the quiz, so were not eligible for the certificate). Many of the responses were general in nature, but we explored which of the various parts of the course were mentioned in answer to the question "What is the main lesson you have learned from the course?" Table 3 shows the number of times students referred to the 12 topics that made up the course. There was good agreement within and between observers. The topic of professionalism was most frequently quoted. The individual duties of the clinician, patient rights and autonomy, legal requirements, and the final topics on healthcare organisation and public health were also frequently mentioned.

The second feedback question asked "Please use this space to give us feedback about the course". The responses were overwhelmingly positive, and the box gives some of the examples. A few students made constructive suggestions such as to change the layout, update the content to include recent developments, and to increase the use of case studies.

Question 3 asked "Would you like to keep in contact about future courses or activities relating to medical ethics? Don't forget to add your email address if so." In total, 37 students submitted their email address.

\section{Discussion}

The course was offered in the context of a programme aimed at health professionals in low- to middle-income countries, and while it attracted students from 60 countries, we were surprised to see that there were relatively more students
Table 3.

Feedback to Question 1: What is the main lesson you have learned from taking this course?

\begin{tabular}{|c|c|c|}
\hline Section title & Topic title & $\begin{array}{l}\text { Number of } \\
\text { mentions in the } \\
\text { feedback that } \\
\text { relate specifically } \\
\text { to the topic }\end{array}$ \\
\hline \multirow[t]{2}{*}{$\begin{array}{l}\text { Rights and } \\
\text { responsibilities }\end{array}$} & $\begin{array}{l}\text { Duties and obligations of } \\
\text { the clinician, including an } \\
\text { introduction to patient rights }\end{array}$ & 16 \\
\hline & $\begin{array}{l}\text { Autonomy, consent, } \\
\text { confidentiality, and the role of } \\
\text { the family }\end{array}$ & 19 \\
\hline \multirow{3}{*}{$\begin{array}{l}\text { Ethico-legal } \\
\text { frameworks }\end{array}$} & Ethical and legal frameworks & 11 \\
\hline & $\begin{array}{l}\text { Mental health and questions } \\
\text { around capacity }\end{array}$ & 0 \\
\hline & $\begin{array}{l}\text { Understanding risk and } \\
\text { questions of disclosure }\end{array}$ & 1 \\
\hline \multirow[t]{2}{*}{$\begin{array}{l}\text { Beginning and } \\
\text { end-of-life }\end{array}$} & $\begin{array}{l}\text { Advance directives and the } \\
\text { right to refuse care }\end{array}$ & 1 \\
\hline & $\begin{array}{l}\text { Issues around the beginning } \\
\text { and end-of-life, including DNR }\end{array}$ & 5 \\
\hline \multirow[t]{3}{*}{ Governance } & $\begin{array}{l}\text { Research governance and } \\
\text { protocols for the protection of } \\
\text { human subjects }\end{array}$ & 4 \\
\hline & $\begin{array}{l}\text { Negligence, misconduct, and } \\
\text { boundaries of responsibility }\end{array}$ & 3 \\
\hline & $\begin{array}{l}\text { Questions of probity and } \\
\text { professionalism, including } \\
\text { honesty and transparency }\end{array}$ & 23 \\
\hline \multirow[t]{2}{*}{ Healthcare } & $\begin{array}{l}\text { Healthcare organisation and } \\
\text { questions of justice }\end{array}$ & 9 \\
\hline & $\begin{array}{l}\text { Essentials of public health and } \\
\text { policy }\end{array}$ & 13 \\
\hline
\end{tabular}

from the global North (and especially from the USA) when compared to the student population attending other courses on the same platform. Possibly due to some publicity derived from the origins of the course, and the number of Indian authors who contributed to the presentations, enrolments from the Indian sub-continent were on par for this course compared to the others courses on the site. Another course on the same site, Medical Professionalism, had 328 students (many of whom enrolled in Medical Ethics Online as well), and an even greater preponderance of students from the global North (62\%). Internet searches seem to have been a potent source for students for the course, rather than word of mouth or referral from others. However, the question remains: how do we attract interest in this area from low- and middle-income countries? We would be interested in discussing possible partnerships with organisations or individuals in India and elsewhere, with the objective of increasing access to this course for those who might benefit.

Among the 12 topic titles covered in the course, the one on professionalism was most mentioned. Not unexpectedly, 
the theme of rights and responsibilities was repeatedly mentioned, but we were somewhat surprised to see that the broader societal issues of healthcare, including public health, were frequently mentioned in the lessons learned. It is unlikely that the choices made by the students represent the quality of those presentations, since each presentation was produced using a common format and was edited by the lead developer to ensure consistency. Rather, it may have something to do with this course existing on a site which has a focus on public health. Furthermore, healthcare organisation and delivery invariably affect the working environment of clinicians as well as the experiences of their patients, making these issues relevant and topical. It might be worth noting these results while developing future courses, or revisions to the course we describe.

The 12 topics chosen in this course match closely the core content of courses suggested by the Institute of Medical Ethics (7), and comprise a comprehensive coverage of the field. Other suggestions cover a more limited list (8, 9 ), and other medical ethics courses available online are restricted to the ethics of research $(10,11)$. The fact that none of our students mentioned research ethics in their feedback suggests that it might be preferable to provide separate courses for practitioners and researchers. There are a number of medical ethics courses available online (911), although most of these are available as higher degree programmes or as massive open online courses (MOOCs) that run to a timetable and are not available between fixed schedules (12). Others may or may not have become defunct (13-15). The other courses we have identified are largely not easy to access or navigate. Pati et al suggest in the context of India (5) "ethics courses are yet to find their rightful place in the teaching of public health in India. The curricula vary across institutes in terms of the time and content devoted to the teaching of public health ethics." Mishra also comments in the lack of public health ethics courses in India (16). We surmise that this is likely to be the case in other settings as well, both in the context of formal public health courses, and those available for continuing professional development for a wide range of practitioners and researchers.

That $31 \%$ of the participants gained a certificate of completion relates favourably to other open courses. We have previously reported rates of $15 \%$ (3) and $11-20 \%$ (17) among Open Online Courses, and that completion rates from most massive open online courses are even lower.

\section{Study limitations}

The experience we describe, and the demographic comparisons we have made between students enrolled for the ethics and other online courses may not be generalisable to other audiences and course contexts.

Quiz scores derived from MCQ tests give an indication of

\section{Some examples of feedback}

\begin{tabular}{|l|l|}
\hline S.No & Responses \\
\hline 1. & $\begin{array}{l}\text { This is an extremely useful and relevant course to modern day's } \\
\text { practice. I found this extremely helpful in clearing some concepts } \\
\text { about professionalism. }\end{array}$ \\
\hline 2. & $\begin{array}{l}\text { The course made clear that a physician providing his/her position } \\
\text { of best patient care must include the patient's rights to make an } \\
\text { informed decision acceptable to both parties involved. }\end{array}$ \\
\hline 3. & $\begin{array}{l}\text {...course is nice because I am in USA and it gives me global } \\
\text { perspective. }\end{array}$ \\
\hline 4. & $\begin{array}{l}\text { Learned about international attempts to unite ethics and priorities } \\
\text { for advancements in advocating both. Much debate will offer } \\
\text { solutions not only in native countries but as a whole system. }\end{array}$ \\
\hline 5. & $\begin{array}{l}\text { This is very good course. Specially for learners in developing } \\
\text { countries. It is good if you can add more activities. Thank you for } \\
\text { the team! }\end{array}$ \\
\hline 6. & $\begin{array}{l}\text { Iappreciate that the course used simply terminology in explaining } \\
\text { often difficult-to-grasp topics such as health care organizations } \\
\text { and policies. }\end{array}$ \\
\hline 7. & $\begin{array}{l}\text { Thank you for the course. It is a broad overview of many different } \\
\text { areas in medical ethics. Future courses may be more specific. Also, } \\
\text { case vignettes and examples helped a lot to understand concepts. }\end{array}$ \\
\hline
\end{tabular}

student understanding on each topic, but they do not allow for different interpretations or judgements. In a clinical setting, ethical judgement usually entails evaluating the evidence that is available and making an informed judgement, as opposed to making a binary choice between right and wrong, so the information for quiz scores is limited and inadequate to assess any impact on practice. The additional criterion for course completion, other than gaining a grade in each quiz, of sending course feedback, was chosen to allow us to identify the potential impact of different parts of the course. These criteria may not be generalisable to other courses with different outcome measures.

\section{Conclusions}

An online course on medical ethics, offered without charge for self-paced learning, reached a wide audience and was well received. Individuals from the global North accounted for a larger share of the student mix for this course compared to other courses on the Open Online Courses platform. This leads us to suggest that further attention should be paid to the recruitment of medical ethics students from low- to middle-income countries. Among the 12 topic titles covered, professionalism was most often mentioned by students in their feedback, which suggests that this aspect might warrant increased emphasis in future courses.

Conflict of interest and funding support: None declared. Contributions: $R M$ and $R W$ conceived the idea for the creation of the course, the curriculum and course development were led RW. RFH converted the course to the format for delivery and supervised the offering of the course through the Open Online Courses site of Peoples-uni.

\section{References}

1. Heller RF, Strobl J,Madhok R. Online education for public health capacity 
building in low- to middle-income countries. Int Rev Res Open Dist Learn. 2019; 20(1).DOI: https://doi.org/10.19173/irrodl.v20i1.3927.

2. Sridharan S, Bondy M, Nakaima A, Heller RF. The potential of an online educational platform to contribute to achieving sustainable development goals: a mixed-methods evaluation of the Peoples-uni online platform. Health Res Policy Syst. 2018; 16:106. DOI: https://doi. org/10.1186/s12961-018-0381-2

3. Heller RF, Zurynski R, Barrett A, Oaiya O, Madhok R. Open online courses in public health: experience from Peoples-uni. F1000Research. 2017, 6:170. DOI: https://doi.org/10.12688/f1000research.10728.2

4. Madhok R. Workshop on Promoting Professionalism and Ethical Practices in Medicine: Indian doctors from across the globe working together. Indian J Med Ethics. 2016 Nov 30 [cited 2020 Mar 21]. Available from: https://ijme.in/articles/workshop-on-promoting-professionalismand-ethical-practices-in-medicine-indian-doctors-from-across-theglobe-working-together/?galley=html

5. Pati S, Sharma A, Zodpey S. Teaching of public health ethics in India: a mapping exercise. Indian J Med Ethics. 2014 Jul-Sep; 11(3): 185-90. DOI: https://doi.org/10.20529/IJME.2014.048.

6. Rao $S$. When corruption becomes the norm and ethical conduct an exception. Indian J Med Ethics. 2016 Jan-Mar; 1(1)NS: 54-7. DOI: https:// doi.org/10.20529/IJME.2016.012.

7. Institute of Medical Ethics. About the core content. Date unknown [cited $2020 \mathrm{Feb}$ 20]. Available from: https://www.instituteofmedicalethics.org/ website/index.php?option=com_content $\&$ view=category\&id=8\&layo ut=blog\&ltemid $=21$

8. Schröder-Bäck P, Duncan P, Sherlaw W, Brall C, Czabanowska K. Teaching seven principles for public health ethics: towards a curriculum for a short course on ethics in public health programmes. BMC Med Ethics. 2014 Oct 7; 15: 73. DOl: https://doi.org/10.1186/1472-6939-15-73.

9. Johns Hopkins Bloomberg School of Public Health. JHSPH Open
Courseware. Ethical issues in public health. 2006 Spring [cited on 2020 Feb 20]. Available from: http://ocw.jhsph.edu/index.cfm/go/ viewCourse/course/EthicallssuesPublicHealth/coursePage/index/

10. Johns Hopkins Bloomberg School of Public Health. JHSPH Open Courseware. Ethics of human subject research. 2005 Spring [cited on 2020 Feb 20]. Available from: http://ocw.jhsph.edu/index.cfm/go/ viewCourse/course/EthicsHumanSubjectResearch/coursePage/index/

11. Johns Hopkins Bloomberg School of Public Health. JHSPH Open Courseware. Introduction to the ethics of human subjects research. 2009 Summer[cited 2020 Feb 20]. Available from: http://ocw.jhsph.edu/ index.cfm/go/viewCourse/course/introhsr/coursePage/index/

12. Massive Open Online Courses (MOOC) List. Ethics MOOCs and free online courses. Date unknown [cited 2020 Feb 20]. Available from: https://www.mooc-list.com/tags/ethics/

13. World Medical Association and Norwegian Medical Association. Fundamentals of medical ethics. Updated 2015 [cited 2020 Feb 20]. Available from: https://nettkurs.legeforeningen.no/enrol/index. php?id=37.

14. Schalow F. Medical ethics. University of New Orleans. Date unknown [cited 2020 Feb 20]. Available from: https://www.learnoutloud.com/ Catalog/Philosophy/Ethics/Medical-Ethics/74709.

15. edX. Introduction to bioethics. Georgetown University. 2019 May [cited on 2020 Feb 20]. Available from: https://www.edx.org/course/ introduction-to-bioethics-2.

16. Mishra A. "Now we feel ethics is everywhere": reflections on teaching a course on ethics in public health practice. In: Mishra A, Subbiah K, editors. Ethics in Public Health Practice in India. Singapore: Springer. 2018; 175-89.DOI: https://doi.org/10.1007/978-981-13-2450-5_10.

17. Heller RF, Chilolo E, Elliott J, Johnson B, Lipman D, Ononeze V, Richards J. Do tutors make a difference in online learning? A comparative study in two open online courses. Open Praxis. 2019; 11(3): 229-241. DOI: http:// dx.doi.org/10.5944/openpraxis.11.3.960.

\section{APPEAL FOR DONATIONS TO THE FORUM FOR MEDICAL ETHICS SOCIETY}

The Forum for Medical Ethics Society (FMES), publisher of the Indian Journal of Medical Ethics (IJME), appeals to subscribers, contributors, readers, supporters and well-wishers of IJME and FMES to donate to its corpus and towards the publication of IJME. Contributions from both individuals and institutions are welcome.

FMES has published the journal on a shoestring budget, without a break, since 1993. The journal is known for being open access and spearheading discourse aimed at advancing social justice in health and ethics-centred healthcare and health research reform. It is recognised widely as an authoritative resource of knowledge in bioethics and allied areas of enquiry. FMES and IJME have not only sustained themselves but have grown over these past 25 years. Our ever-growing base of readers, contributors, and reviewers enables the publication of multiple and diverse perspectives on wide-ranging topical areas. We have also striven to upgrade the journal technically to keep up with the advances in publishing to widen our reach. This has been possible only because of your steadfast and sustained support.

We are committed to maintaining our editorial independence which is critical to safeguarding the scientific integrity of what we publish. Therefore, wider support from all those who are committed to social justice in health is essential.

FMES is registered under the Societies Registration Act, 1860 (Reg No: Mumbai-218-1995-G.B.B.D.D) and the Bombay Public Trusts Act, 1950 (Reg No: F-17441 Mumbai, 1995), and donations are eligible for tax exemption under Section 80G of the Income Tax Act, 1961

For more details on how to support us, write to admin@ijme.in or visit our website www.ijme.in/subscribe-support/

$$
\begin{aligned}
& \text { SUPPORT OPEN-ACCESS ACADEMIC PUBLICATIONS, } \\
& \text { DONATE TO THE FMES CORPUS FOR THE PUBLICATION OF IJME! }
\end{aligned}
$$

